\title{
Time Traces: Cultural Memory and \\ World War II in Pohnpei
}

\author{
James West Turner \\ and Suzanne Falgout
}

While conducting fieldwork in Pohnpei, Micronesia, Suzanne Falgout heard poignant accounts of the Islanders' experiences during World War II. Today, sixty years after the war, these memories are still immediate, painful, and intensely personal for members of the wartime generation. Researchers working in other places in Micronesia and elsewhere in the Pacific have also found that the war years figure prominently in local consciousness. ${ }^{1}$

Pohnpeian reminiscences about the war take the form of personal narratives, anecdotes, jokes, and songs. These verbal performances are especially common during nighttime kava-drinking sessions. In Pohnpei, kava drinking is an important part of social life. The setting is often a farmstead meetinghouse where family members, neighbors, and friends gather, but kava is also drunk in commercial kava bars distributed along the circumferential road and in Kolonia, the capital of the Federated States of Micronesia (FSM). Discussions over kava that include war stories often end in the singing of one of the many wartime songs that remain popular on the island today.

Under wartime conditions of Japanese censorship, most Pohnpeians knew very little about the war except for their own personal experiences. Curiosity about the wider scope of events remains evident among this generation today, and continual sharing of personal wartime experiences over the years has helped formulate a much wider vision of the war. But the elders tell war stories and sing songs not only to satisfy their curiosity and desire for reminiscence, but also to provide guidance for the future. Parents and grandparents retell these stories to the young "so they will know about war and the hardships it brings."

The Contemporary Pacific, Volume I4, Number I, Spring 2002, IOI-I3I

(C) 2002 by University of Hawai'i Press 
In this paper, we discuss not only the contents of these Pohnpeian collective memories of the war but also some broader theoretical questions they provoke. We begin by critically examining common understandings of the nature of memory and its relationship to time and agency. Next, we discuss the relationship between personal and cultural memory, outlining the processes through which personal experiences are transformed into cultural memories. Finally, we examine the nature of Pohnpeian memories of the war and the transformation of these personal memories into collective ones. We explore the relationship of these memories to other forms of Pohnpeian knowledge of the past. Finally, we discuss the changing use of war memories in the evolving social and political contexts in contemporary Micronesia.

\section{ON MEMORY}

\section{Memory and Time}

When people speak of memory they usually understand the term as referring to a process or faculty through which images or impressions of the past are recalled in the present. But this analysis of the word's usage is inadequate. Close attention reveals that what is remembered is not limited to the temporal plane of the past. Suppose someone rummaging through a desk encounters a newspaper clipping, glances at it, and exclaims, "I remember this." What is being said is not that they remember the past act of clipping the article or putting it in the drawer, but that they recall the article, something that still exists in the present. Similarly, someone who claims to "remember" an upcoming appointment is not referring to a past action (that is, having made the appointment). Rather, they are calling to mind in the present an event (the appointment) that lies in the future (DeConcini I990, 3). Everyday language accepts that objects of memory are not necessarily limited to the past. Memory functions as a way of transcending time. It is as much prospective as it is retrospective, providing a means "for interpreting our experiences of the present and [allowing] us to foresee what likely lies ahead" (Fentress and Wickham I992, 5I). Memory's evolutionary value lies in these interpretive and prospective qualities.

The tendency to equate memory with the re-presenting of the past is associated with some deeply embedded cultural assumptions about the nature of time. Scholars have long noted a tendency in western thought to objectify time; that is, to view time as an aspect of the world as it exists rather than as an aspect of the way western minds experience that world. 
This objectified medium we call time is also spatialized: it lies "behind" us or "before" us. In speech as well as in the symbolism of dreams, myths, and rituals, life is often likened to a journey or movement through or in time-as-space. Time is also quantified, by being parsed into uniform segments of various "lengths" that "flow" at a uniform rate. Seconds, minutes, hours, and longer segments can be counted off like beads on a cosmic abacus (see Whorf I956).

One of the corollaries of this treatment of time as objectified, spatialized, and quantifiable is the idea that only the present can be known with certainty. The past is gone, and the future has not yet come into being. From this it follows that perception provides the surest experience of an external reality. Memory connects people with the past, and imagination allows them to anticipate the future, but perception roots them in what really is, the present. The result is that in modern western thought, "imagination and memory tend to be viewed as twin faculties of low epistemic status derivative from perception" (DeConcini I990, 3).

If memory is thought to have its basis in past perceptions, then memory may be regarded as a trace or copy of the past. But like other kinds of images, memory can faithfully portray the reality it represents or it can distort it, raising the further problem of discriminating between true and false memories and the related issue of distinguishing between memory and imagination.

Fentress and Wickham (1992) attributed the gradual devaluation of memory in the west to the simultaneous rise to dominance of textual models of knowledge, a phenomenon in turn linked to the development of printing, the increasing availability of books, and increased literacy during the Renaissance. Verbal utterances and discursive interchange are performances, gone at the very moment they are experienced and (prior to the invention of modern recording devices) only retrievable through memory. Writing creates texts that can be compared, analyzed, and reexperienced. But written texts are always more organized and less spontaneous than thought processes or thoughts expressed by spoken word; moreover, they readily lend themselves to semiotic decoding. For this reason written texts, even texts about reminiscence, can never fully capture the rich modalities of memory.

If knowledge is thought of as a text, the faculty of memory can be likened to a mental filing cabinet. Some of the information stored there is assumed to be objectively true. The veracity of particular texts (recorded memories) can be evaluated by assessing their internal consistency and 
cross-checking them against other texts. In this sense, particular memories can be treated as detachable from the person who remembers. Similarly, while it is acknowledged that sensations are inseparable from the perceiving mind, western epistemology treats knowledge as something separable from the knower. Assertions may be true or false independently of the person making them, and what persons know belongs to them only in a temporary and contingent way, because what one knows, others may know as well. However, sacred knowledge in Pohnpei is thought of as an aspect of the knower, a point we discuss later.

\section{Memory and Agency}

Viewing memory as a container in which (often suspect) texts may be stored for future retrieval overlooks the diversity of forms that memory can take (see Connerton 1989). Semantic memory involves the recall and correct usage of linguistic categories-for example, the names of persons, places, things, qualities, activities, and so on. Sensory memory involves the recognition of, and response to, the evocative quality of sensations, as when certain smells, sounds, textures, and the like mentally transport people to a past time when similar sensations were experienced. Somatic or corporeal memory involves motor patterns and skills that, once learned, can be reactivated when needed. Finally, recollection is a kind of experiential memory. It involves the re-presenting of life episodes experienced in the past. It is the most complex form of memory because it can incorporate remembered conversations (dependent, of course, on semantic memory), various sensations (sensory memory), and actions.

The textual analogy discussed earlier is most applicable to experiential memories, which lend themselves to narrative structuring. But the analogy is clearly inadequate to the task of representation for, like dreams, the complexity of experiential memory can never be fully captured by a written or spoken text. Since cultural memory depends on articulation through narratives, monuments, rituals, or some other form of representation, it also simplifies the complexities and ambiguities of personal memory.

Furthermore, these four modalities of memory are realized in acts of recognition, recall, and reminiscence (Fentress and Wickham 1992). When people recognize a person or thing, they are identifying what is present by reference to previously acquired knowledge or experience. In contrast, in the act of recall, the object of memory need not be present; rather, it is re-presented through an act of mind. Finally, when reminiscing, people communicate to others what they recall. 
Representing the faculty of memory as a mental container disregards human agency in the acts of recognition, recall, and reminiscence. In all of its forms memory involves simplification, schematization, and interpretation. The active nature of memory is reflected in the word's etymology. The English word remember is derived from the Latin word memorari, and memorari shares a core of meaning with narrare, the source of the English word narrate. Both meant "to narrate, to tell a story" (DeConcini I990, 62). Telling a story always involves acts of choice about which details to include, which characters or actions to stress, and so on. As we show later, the songs and stories that encode cultural memories of the war in Pohnpei reflect this active shaping and selection, which explains why they echo the tropes and themes of traditional tales.

As noted, western epistemology has been mistrustful of memory as a basis of knowledge since the Enlightenment. Perception, on the other hand, has risen to a central position in western theories of knowledge. In the empiricist tradition, it is held to provide insight into an objective reality that exists independently of the perceiving mind. However, the active role of memory is highlighted in some theories of perception, which is seen as being "organized via anticipatory schemata whereby the individual anticipates new, incoming information while simultaneously digesting the old. ... Because schemata are anticipatory they are 'the medium whereby the past affects the future' which is 'identical with the underlying mechanisms of memory" (Giddens 1984, 46; internal quote from Neisser 1976, 22).

Just as residues of the past can be seen as providing an organizing framework for perceptions in the present, so do other traces of the past in the present make human culture possible. Symbols are central to culture, but their ability to convey meaning depends on rule conformance. Symbols acquire their meanings through conventions of usage, so in order to be meaningful, on each occasion their use must conform to those rules of usage. Rule conformance, and recognition of conformance, is dependent on memory. Symbols are combined to form the prescriptions, patterns, rules of thumb, techniques, and so on that govern cultural behavior, but again the cultural appropriateness or correctness of a behavior can only be judged by reference to memory.

Most cultural behaviors are produced in an unselfconscious way in accordance with habitual patterns of thought, feeling, and action. These habitual structures are also residues of the past in the present and capable of shaping the future. The cultural modulations of the senses, the cultural shaping of the emotions, and the culturally patterned carriage and motor 
patterns with which people operate in the world also constitute types of memory. It follows that any social theory that purports to describe cultural behavior must take the active role of memory into account.

\section{Personal and Cultural Memory}

Memory is not only central to the process of perception and the recognition of rule conformance but is also the foundation of personal identity. That is, the sensory memories of the embodied mind are the principal source of a sense of self. From them people construct a memory of self, and the memory of self convinces them of their own continuity through time. This sense of connectedness between present and past allows people to maneuver through the routines of everyday life. The fear that Alzheimer's disease and other forms of dementia inspire arises from the severing of these connections and the resulting dissolution of self and personhood. The erasure of cultural memory can have similar consequences for collective identity.

Just as personal memory is the basis of individual identity, so is cultural memory crucial to collective identity. But in a sense is memory not always cultural, in that the person who remembers is a cultural product? Conversely, to the extent that the cultural representations that are collectively remembered have their basis in the personal memories of individuals, is cultural memory not also personal? (Hirsch 1995, I3-I4; Fentress and Wickham I992, 7). Here we examine the linkage between what is personal and what is cultural, highlighting both the interconnectedness and the important differences between these two types of memory.

Dramatic events and memory. Certain dramatic and culturally salient aspects of the past are more likely to be remembered than more commonplace occurrences. The routines of daily life are seldom preserved in memory, but why should this be so? Why should the common occurrences of everyday life be so easily forgotten? Should not their familiarity and frequency ensure remembrance? Repetition has the effect of effacing previous memories, as Fentress and Wickham pointed out (1992). They use the example of subtle changes in people's faces that, even though they may be observed daily in the mirror, go undetected, not because they are too slight to notice, but because of the very habitualness of the act of observation.

However, while conscious memory of the details of everyday lives may not be preserved in cultural memory, certain basic cultural categories that underlie everyday behavior may persist. These include categories relating to space, time, personhood, and causality. Some aspects of quotidian 
behavior may also be retained over long periods, such as posture, proxemics, and motor patterns; these too constitute a kind of memory-corporeal memory.

Dramatic events such as disasters, societal triumphs and defeats, or politically formative events such as revolutions or liberation struggles are more likely to be remembered than the more mundane events of everyday life. But dramatic impact or collective trauma alone is not enough to ensure remembrance. It is also necessary that the event fit somehow within existing cultural categories and "established structures of thinking and feeling” (Irwin-Zarecka I994, I 2 I). For example, Lauriston Sharp (I952) reported that he was unable to elicit any collective memory on the part of the Yir Yoront of a disastrous encounter with Australian cattlemen that had taken place in I 864, seventy years before his fieldwork.

Preserving and codifying memories. Cultural mnemonic devices help to preserve and codify memories. The ability of individuals and societies to recall their respective pasts is fragile and subject to erosion. To combat this, societies around the world have developed many different types of mnemonic devices. Language itself is a powerful aid to memory in that it allows people to organize their experiences into conventional categories, facilitating recall. Linguistic features such as rhyme, alliteration, rhythm, and descriptive formulae add to the mnemonic power of language, and proper names and etymologies may also function this way. As well, genealogical frameworks can be powerful aids to memory insofar as they provide reference points for dating and remembering events of the collective past.

In addition to language, human societies have made use of a wide variety of physical objects as memory aids. Material things can be seen, touched, even held and handled. Over time and through repeated use, such objects may become part of the past that they are designed to recall. Buildings, ruins, the hair or bones of the revered dead, or other physical remnants are often preserved specifically for the purpose of keeping the present linked to the past.

In many societies the landscape itself serves as a record of the past. In societies practicing shifting agriculture, events that took place in the past are often dated by reference to garden sites and other named locations, so that stories about the past take the listener on a journey through a wellknown landscape (Rosaldo I980). Because significant places are often named, the names themselves may evoke remembrance and nostalgia (Schieffelin I976; Weiner I99I).

One of the most elaborate mnemonic systems ever devised was based on 
this power of places and objects to evoke remembrance, but in this case the places and things were all images in the mind: the memory palaces advocated by Renaissance writers on the art of memory. It was recommended that these mental constructions, in the form of large buildings or public spaces such as markets, be places well known to the practitioner. Each room or stall could be mentally divided into separate spaces, and in each space a mental image could be stored, the characteristics of which called to mind whatever one wanted to remember. An act of memory became a mental journey from room to room to retrieve the desired information. On learning this system from a sixteenth-century Jesuit missionary, one young Chinese man remarked that remembering the system took as much effort as memorizing the facts to be stored in the memory palace (see Spence I984).

Construction of cultural memories. Cultural memories must be purposefully constructed. Here the word construction is used to mean a kind of deliberate work or effort of remembering. The effort may involve large numbers of people performing different kinds of memory work and may take on truly industrial proportions. Think, for example, of the various ways in which the deaths and sufferings of millions of individuals have been transformed into the collective memory of the Holocaust. Historians, filmmakers, publishers, governments, writers, artists-all have contributed to the construction. But the fact that images of the past are culturally constructed should not be taken to imply a discursive free-for-all in which anything goes. The determinate past itself sets limits, as do power relations in the present (Turner 1997).

The construction of cultural memory is both similar to, and different from, acts of individual memory. As individuals each person has an infrastructure of memory, or what Irwin-Zarecka (1994) called memory households. Photographs, mementos, favorite books, names inscribed in the cement walkway of a home - all have the effect of anchoring individuals to their remembered pasts. So important are these markers of memory that their loss or destruction may produce disorientation or, in extreme cases, undermine the integration of personal identity.

Individuals deliberately construct personal memories in ways analogous to the construction of cultural memory, but since cultural memory only persists through time if each new generation renews the effort of construction, it is inherently fragile in a way that personal memory of the past is not. Of course, everyone has experienced the frustration of being unable to recall a fact or a name when desired, but everyone has also had the experience of a memory, unbidden, evoked by a scent, a piece of music, a 
taste, or some other sensory stimulus that happens by chance. In contrast, once they are forgotten, cultural memories, in a sense, are gone forever. Traditions can be reinvented and histories reconstructed, but unless there is continuity through time, how can calling these memories be justified?

Articulation of cultural memory. Cultural memory is always articulated. Through acts of articulation, personal experiences are transformed into cultural memories. These shared memories are representations of the past that bind together communities that may be dispersed in space as well as time. The articulation of cultural memory often takes the form of written or spoken texts but can also be encoded in other media such as rituals. For example, the important religious holidays of Judaism commemorate events that took place at various times in the distant past, some of which cannot be historically documented (Irwin-Zarecka I994, 57). In the various world religions as well as nonliterate religious traditions, ritual often involves anamnesis, a re-presenting of the past "so that it becomes alive and active in the here and now" (DeConcini I990, 60). For example, the Roman Catholic sacrament of Eucharist reenacts the Last Supper, at which Christ, by offering bread and wine to his disciples, foreshadowed his own sacrificial death. Through transubstantiation the bread and wine of communion are transformed into that sacrificial body and blood. The annual peyote hunt pilgrimage of the Huichol Indians of north central Mexico provides another example of anamnesis through ritual. Before setting out on their journey, the pilgrims shed their mortality and become the ancestral deities who made the first such pilgrimage (Myerhoff 1974).

Monuments, too, can be used to transform personal memory into collective remembering. Debates about the designs of monuments and commemorative displays like the Vietnam War memorial or the Enola Gay exhibit or the controversy over the Confederate battle flag are partly disagreements over whose memories should be given public expression.

Cultural transmission of memories. Images of the past must be conventionalized so that they will be meaningful to an entire culture, and they must be simplified to aid in transmission (Fentress and Wickham I992, 48-49). Just as actual events are more complex, ambiguous, and chaotic than individual memories of them, personal memory will always be far richer than the images of collective memory. When cultural memory is articulated, characters and events tend to be reduced to cultural archetypes, just as culturally specific narratives may be used to apprehend historically unique events (Sahlins I98I, I985) or to make sense of the twists and turns of individual lives (Young I983).

Political implications of construction and articulation. The processes of 
construction and articulation of cultural memories always have political implications, for several reasons. First, both construction and articulation are interactive processes affected by differences of power. Second, even in relatively homogeneous societies a parallax effect emerges in the construction and articulation of cultural memory: persons of different genders, descent groups, communities, or other social groupings often have different perspectives on the cultural system and opposed interests in how the past should be remembered. Third, what people choose to remember about the past (and what they choose to forget) as well as how they represent the past to themselves and others influences how they live their lives, thus affecting political relations both within and between cultures (see Hirsch 1995).

\section{Pohnpeian Cultural Memories of War}

If it is true that dramatic, traumatic, and transformative events are likely to be preserved as cultural memories, then it follows that World War II would loom large in Pohnpeian collective memory. During that war Pohnpeians were caught in the middle of what for them was a foreign conflict. The Japanese had taken over administration of former German possessions in Micronesia at the start of World War I. During the twentysix years of Japanese administration, Pohnpeians had developed a measure of loyalty to Japan and feelings of respect for, and attachment to, individual Japanese. Now they were caught up in the sweep of the American advance in the Pacific. As the tide of the war turned against the Japanese, the military administration of the island became increasingly harsh. Pohnpeians were subjected to demands for forced labor and land; food and possessions were subject to confiscation. Pohnpeians were relocated on their island, and some were sent to other locations in Micronesia and to the Southwest Pacific. Since American forces had suffered heavy losses in earlier invasions of other island groups, wherever possible they adopted a strategy of blockading, neutralizing, and bypassing Japanese-held islands in their push to Japan itself. This strategy would bring other kinds of hardships to Pohnpei: shortages of food, clothing, and medical supplies as well as the constant threat of air and sea bombardment over a period of nearly two years (see Poyer, Falgout, and Carucci 200Ia).

These Pohnpeian experiences in World War II resonated with earlier important customs and with earlier periods of hardship and change through contact with outsiders. In Pohnpei, warfare was the "custom of 
men.” A man's bravery in battle (and agricultural ability, to a lesser extent) in service of his chief was a major means of achieving high title and status (Fischer 1957; Riesenberg 1968). Many of Pohnpei's most prized legends and revered archaeological sites related to ancient battles (Bernart 1977; Hambruch 1932, 1936; Falgout 1987). Over the century of contact before the war, this bountiful and centrally located island had attracted more than its share of outsiders-whalers, traders, beachcombers, missionaries, and colonists - who brought with them numerous changes of increasing scope and intensity. The presence of outsiders frequently contributed to internal social upheavals on the island-prostitution, drunkenness, epidemic diseases, massacres, new types of battles, and even colonial rebellions (see Fischer 1957; Hanlon I988; Hezel 1983) - as well as a measure of connection to the outside world.

Within these contexts, however, World War II represents the most intense and catastrophic encounter of Pohnpeians with the outside world. The surprising speed with which the war swept over them and the magnitude of the disruption it brought were profoundly transforming. Like other Micronesians, Pohnpeians often liken it to a typhoon, an unstoppable force of nature that leaves death and destruction in its wake (see Poyer, Falgout, and Carucci 200ra).

Clearly, World War II was a watershed event in modern Pohnpeian history. Under the most unexpected and trying wartime conditions, Pohnpeians were forced to stretch to the maximum their individual and collective abilities to survive. Suddenly and forcefully they found themselves immersed in certain aspects of life in the modern world. As in other areas of the Pacific, the war also brought to Pohnpei revolutions in technology, transportation, and communication (see White and Lindstrom 1989; Lindstrom and White 1990). Pohnpeians marveled at the strategic knowledge of the Japanese and Americans about people and places unknown to Pohnpeians, and they were awed and frightened by the destructive capacity of their sophisticated weaponry.

While the war brought these dramatic changes to their island world, it also helped to usher in a host of further changes in the postwar period. At war's end, with equal suddenness, Pohnpeians would shift their role from that of relatively isolated colonial dependents to that of increasingly active participants in the global community, a situation for which they had only limited preparation (Poyer, Falgout, and Carucci 200I b).

Life in Pohnpei, then, was rapidly, forcefully, and irrevocably transformed by the war and its aftermath. Those who experienced the intense suffering during the Japanese military buildup and the American campaign 
describe it today as the greatest hardship they ever endured (see Falgout 1989, I99I, I995). For older Pohnpeians, their ability to endure and survive the hardships of the war years is a source of individual and collective pride. Memories of the war are bittersweet; the act of narrating war tales allows the storyteller and the audience to reexperience the fear and loss as well as the pride. Through text and performance, Pohnpeian stories and songs transform important personal wartime experiences into powerful collective memories.

\section{Pohnpeian Forms of Wartime Remembrance}

Pohnpeian memories of World War II have been encoded into a variety of traditional forms of remembrance that aid in transforming personal experiences into cultural memory. The use of conventional genres, tropes, characters, and concerns found in the oral traditions help to give the war stories their characteristic shape, as well as an evocative quality (Mageo 200I). In the various forms of reminiscences about the war, individual Pohnpeians are usually explicit about the emotions they experienced. Personal emotion is rarely mentioned in public discourse, but it seems not only acceptable but perhaps even expected when referring to wartime experiences. Such revelations make stories and songs more vivid and emphasize to listeners the dramatic nature and significance of these events.

Pohnpeian oral traditions are replete with tales of first arrivals to the island and of ancient battles. The sudden and dramatic arrival of the war in Pohnpei, dated to the start of the American bombing of the island, is very frequently told by those who experienced it. War stories are typically recounted with great emotion and attention to detail. Mr Andonio Raidong, who had been passing through the town of Kolonia the day the bombing began, reported:

I almost died at the bridge of Doweneu [Net chiefdom]. The planes started dropping bombs there. I was coming from Palikir [Sokehs chiefdom] to see my family. A soldier asked me where I was going. I said, “To Net.” He said, "Hurry, the planes are coming." I reached Namiki (in Kolonia) and the siren in the post office went off. Everyone hid. I rushed off toward Net. This is where I met a man. I was standing by a house near the bridge when four huge planes approached. I walked under the bridge to hide, and soldiers there saw me and said, "Hey there, watch those planes; they'll kill you if they see you." I ducked down and a man from Net joined me, just as four bombs went off. One bomb was only six feet from the bridge; three others landed in the water. The Americans were trying to blow up the bridge so the Japanese soldiers couldn't walk on or hide under it. So, I told the other man, "Let's run." 
When we started to run, a Japanese soldier told us to go back and hide under the bridge. We were more afraid of the bombs than of the Japanese soldier, so we just took off. When we were trying to climb up from under the bridge, I was wearing tabis and I kept slipping back, but the other man was barefoot and climbed out faster. We kept running to a house called pampei, a guardhouse. I jumped over something that I thought was a piece of wood. I realized that it was the foot of one of the soldiers. Then I jumped into a ditch and bombs kept exploding. I reached the bridge where the Net office was located. The people there said to stop running because the bombers had already left. But I kept running anyway. I met other people from Net who were looking for their kids at school. School was still being held in Kolonia.

I almost died. (Raidong I990)

As can be seen in this story, World War II for Pohnpeians (if not the major combatants, their commanders, and military historians) was both very personal and very local. That is, these narratives portray the war as a catastrophe visited on a landscape that Pohnpeians know in intimate terms. In Pohnpei the past is as much a matter of place as it is of time, since all significant events take place in locations that are themselves significant. For this reason stories and songs about World War II often include not only the names or titles of the principal characters but also the names of the places where events occurred. And, since Pohnpei has been inhabited for a very long time, any given place within this landscape of memory may have multiple associations with respect to different periods in the past. The island itself is like a palimpsest on which many different stories have been inscribed. To the cultural insider, situated stories, including war narratives, can have a subtext insofar as each story or story fragment echoes other stories associated with a place (see Poyer 1992).

The reworking of several traditionally important characters and tropes occurs in some of the best-known Pohnpeian stories of the war. Many stories employ the character of the clever young man of ancient Pohnpeian myth and folklore, such as Satokauai, who, having incurred royal wrath in eating a large yellowfin tuna, redeemed himself by accomplishing the set task of locating and presenting a rare shell to the island's paramount chief, the Saudeleur (Bernart 1977, 38-4I). Other stories use the theme of the (seemingly) less powerful or socially inferior person using his wits to win an advantage over a more powerful superior. This theme is found in the ancient tale of Isokelekel, son of the thunder god who once was imprisoned and then escaped downwind. Isokelekel returned to Pohnpei as a young man, hiding his identity and strength and awaiting an opportune moment to overthrow the Saudeleur (Bernart I977, 73-76). (Isokelekel 
then decentralized rule by establishing several independent chiefdoms, each eventually led by the Nahnmwarki [paramount chief] and Nahnken [talking chief] lines of title [Bernart I977; Hambruch I932, 1936]. This chiefly system still exists in modified form.)

In the mildest versions, stories of clever Pohnpeian responses to instances of oppression by Japanese soldiers recount tricks played on the Japanese. In such stories, Pohnpeians show their resistance and occasionally their revenge. Mr Keropin David, a member of the postwar generation, related one such anecdote he heard while drinking kava with a family member:

There were some funny stories that I heard about the war. There was one man who was my mother's first cousin . . his name was Dorip Mauricio. And, I heard this story from him; he talked about it while we were drinking kava.

During Japanese times he was young, and he was not in the group who went to Kosrae. But, he used to take [Japanese] people from Wene to Sapwalap by canoe. If one soldier delivered a message to the others in Sapwalap, this man paddled him up to Sapwalap. He was not kind to the Japanese soldiers!

[One] story was about [Dorip] and another guy who took one soldier to Sapwalap, and when they came back the soldier wanted to drink coconut juice, so they stopped at one of the small atolls and he climbed one of the coconut trees that curved over the lagoon. When he was in the tree, he told the other guy to paddle the canoe up so that the soldier was positioned under the coconut tree, because he was going to cut the coconuts and let them fall on top of the man. So when the other guy paddled the canoe up, he cut the coconuts and they fell on the soldier.

Some Pohnpeians had a good time doing bad things to the Japanese! (David I99I)

Trickery as resistance is also a major trope found in stories about the I79 Kiti men sent to Kosrae (discussed later). In these stories, the coerced nature of Pohnpeian participation is usually quite explicit. Pohnpeians typically discuss how especially precarious their position was vis-à-vis the Japanese soldiers because they were so far away from their home island and the support of their families and friends. They also often demonstrate that through their bravery and shrewdness they were able not only to survive but sometimes to gain a relative advantage (Falgout 1984, I989, I992). The stories make the point that, if the Pohnpeians could not themselves overthrow the increasingly harsh Japanese military, they could at least occasionally outwit them. While outwardly bowing to overwhelming Japanese power, these Kiti men undermined Japanese prestige and efforts at every opportunity. 
In these narrated memories the same kinds of concerns are expressed as in important historical narratives. Specifically, what the war stories highlight are the nature and quality of social relations. War stories display traditional Pohnpeian preoccupations with status, kinship, and sharing, especially the sharing of food (see Falgout 1989). The nature of the power relations between the major combatants and Pohnpeians is often stressed, as are the strong bonds forged by shared suffering among Pohnpeians themselves and between Pohnpeians and other Islanders. The theme most commonly expressed in Pohnpeian war stories is that of the tremendous hardships they suffered as a consequence of a foreign war-constant fear, separation from loved ones, relentless work, harsh discipline, sickness, and critical shortages. However, perhaps because of the repetitive, enduring, almost chronic nature of such experiences during this period of greatest hardship, although they are frequently mentioned, they are not given great narrative elaboration (see Carucci 200I).

Chants and songs were used by Pohnpeians as historical mnemonic devices as well as entertainment (Falgout 1984). Their use was both encouraged and transformed over the entire contact period, including the Japanese colonial era. Songs composed during the war were in either Pohnpeian or Japanese, or, often, a combination of both. Singing styles include traditional Pohnpeian forms, missionary-inspired hymn styles, and tunes bor rowed from the Japanese. Some songs deal with working conditions on particular wartime projects, such as fishing or on agricultural plantations; others detail personal encounters, including those between men and women. These songs about work and personal encounters are put to more informal tunes known and sung by only a few. Some of these less formal songs recount the misery of war; others are teasing, self-deprecating, or bawdy.

Two Kiti women working on a plantation in Palikir (Sokehs) composed a song that mocked the arrival of two amorous male visitors from the rival chiefdom of Uh. Women working on the plantation sang this song as a form of amusement while they worked. Today, it is still known and occasionally sung by Pohnpeian women who worked on that plantation and by a few others.

You [honorific] are a little bit smart and have moved up a little to a higher status.

Seems stupid you give yourself to me.

I'm sorry, because [I] do not enjoy you.

(Interview with plantation worker, Ms Lihna Lawrence, 1990.) 
Other war songs are cast in the formal style of Pohnpeian memorial songs. Memorial songs usually follow a significant event, such as the death of a notable or beloved person. This use of a musical form locates wartime experiences within a cultural scenario of tragedy and loss. One example is the "Memorial Song of Kosrae," which relates the experiences of I 79 men of Kiti chiefdom who were relocated to Kosrae by the Japanese during the war. The song was originally composed by two of the Pohnpeian supervisors of the migrants. Though cast in the memorial song style it is set to a Japanese melody; it is sung in Pohnpeian but employs some Japanese terms (see Falgout I989). Within a very serious traditional song genre it combines traditionally important acts of bravery with an unusually harsh example of forced relocation and includes an especially open expression of wartime sentiments. This song has become a particularly important component of Pohnpeian collective memory of the war. It is still known and sung today, not only by the Kiti men but more widely around the island.

I. Running there, we suddenly see Kosrae

with mountains like those of Kiti chiefdom.

I begin to recall our happy chiefdom

from which we were forced far away.

2. At one o'clock we reached the open sea of selfishness ${ }^{2}$

all of us prepared and going forth.

Myself, I believe there is no authority

for throwing my life away. ${ }^{3}$

3. All of us total I79.

Four went away from us;

Six died.

Chorus: Quietly resting from our servitude.

Free from death.

All of us enjoy singing

praise to our Nahnmwarki

who is the ruler of the world. ${ }^{4}$

There is shocking news. ${ }^{5}$

Maybe we were dreaming.

(Interview with one of the song's composers, Mr Linter Hebel, 1985)

In whatever style they are sung, war songs make wartime information more memorable and codify and preserve it for the future (see also Lindstrom and White I993). 
In addition to narratives and songs, many Pohnpeians' memories of the war are also preserved and even embodied in cherished Japanese mementos, such as military paraphernalia or photographs from the Japanese colonial era. Falgout found that photographs have an uncanny ability to evoke peoples' memories and emotions. For a brief moment they seem to transport elders back to the time when the shutter was snapped. Such tangible mementos add a special authenticity to the personal reflections expressed in songs and narratives.

The transformation of personal memories into collective ones is facilitated by the existence of suitable traditional genres, tropes, characters, and objects into which wartime memories have easily been encoded and even expanded. It is also facilitated by the existence of contexts, such as kava drinking, during which these memories can be articulated. No doubt these traditional genres and forums have served to enhance the importance of wartime memories over the last sixty years.

\section{Memory Work and the War in Pohnpei}

Pohnpeians continue to articulate personal memories about World War II, and the war has become a salient part of cultural memory, partly because of its scope and violence. As we have noted, Pohnpeians talk about the war as sweeping over them like a force of nature beyond their control, disrupting the routines of everyday life, making such necessities as food and shelter uncertain, and threatening their very survival. From another, equally significant perspective, it was not a natural disaster but a human event with lasting political consequences. The war lies at the root of modern Micronesian nationhood, and, as we discuss later, remains an important issue in the relationships of the Federated States of Micronesia with other nations.

Today reminiscence about the war is more than just reverie on the part of elders. In the transformed social reality of independence, memories of the war have taken on an intergenerational significance. It is a rare Pohnpeian youth who cannot retell a story of the suffering of the Islanders under Japanese military rule, identify suspected American spies by name, hum a few bars of a war song, or (like Mr Keropin David) tell an amusing anecdote of Pohnpeian wartime cleverness and trickery. In the consciousness of generations who did not directly experience the war, wartime experiences live on, albeit in a somewhat truncated and stereotyped form.

The recounting of these experiences has helped to forge a much wider 
vision of the war, and even a sense of camaraderie with other people and places linked to those difficult times. In the war years, as the conflict approached and then swept over the islands of Micronesia, news was tightly restricted by the Japanese. Except for the few individuals closely tied to the Japanese, such as the highest chiefs, persons with advanced education working in the Japanese administration, and those connected to Japanese citizens by marriage or special friendship, most Pohnpeians knew very little about the war except for their own personal experiences. Censorship produced a fragmentation of knowledge about the war, which in turn spawned an enduring curiosity about what was happening in other wartime arenas, especially where loved ones were stationed. Trading war stories reinforces wartime bonds-strong ones forged even among strangers whom the war swept up together. The act of sharing reminiscence also creates new bonds in the present, even between individuals meeting for the first time.

Furthermore, stories and songs about the war are often accompanied by commentaries that reflect on present-day implications of wartime experiences. Listeners are told that they should take pride in Pohnpeian traditions that made survival possible. Stories about the past of lived memory are understood to point up the value of practices that are identified with a still more distant past, while also demonstrating the relevance of custom in the present and future. Commentaries also call attention to the wisdom gained from the hard lessons of war (see Falgout 1989). These lessons about modern war and the world system are often referred to in discussion of the postwar period of American administration and the future direction of the Federated States of Micronesia.

In recent years war stories and songs have been more widely disseminated by new forms of technology that allow them to be experienced by more people and in new social contexts. Today, the best of the old wartime songs have been recorded on cassettes that are circulated among friends; they have even become favorites on islandwide radio broadcasts, which are still the most important form of mass communication in contemporary Micronesia. Although oral recollections remain the most important medium of communication about the war, books and especially video recordings about World War II in Micronesia, the wider Pacific, and elsewhere are also very popular. The islandwide collection and dissemination of war-related works of memory has engendered more widely shared understandings about the war and Pohnpei's role in it, and has contributed to the spirit of local and national pride found in Pohnpei today. State and 
national governments have recognized the importance of the war in this regard and have sponsored some locally produced videos that make use of documentary footage and interviews with Micronesian elders. These efforts have also been supported by the local historic preservation office in Pohnpei and its counterparts in the other federated states. War materials are now seen as important enough to collect and curate in local archives.

In the postwar era, yearly ritual commemorations and reenactments of the war developed in many Micronesian locations, often on the anniversary of the end of the war for a particular island location, usually on a particular island's liberation day. These celebrations involve different events and are elaborated to different degrees throughout the region. The initiation of Pohnpei's Liberation Day celebration is usually credited to the Etcheit family-expatriate Belgian entrepreneurs who spent the war on Pohnpei imprisoned by the Japanese military. The celebration marks the arrival of American forces on 9-Io September. As in several other parts of Micronesia, it includes church services and speeches that recall the events of war and liberation and the importance of freedom. However, the primary focus is on shore and field athletic competitions.

Thus, memory work relating to the war goes on at various levels and in a variety of contexts, from informal discussions around the kava stone to radio broadcasts, video recordings, and government policy. The memories themselves clearly have a role to play in forging a modern Pohnpeian and Micronesian identity.

\section{Knowledge of the Past in Pohnpei}

Despite the cultural importance attached to experiences of World War II and the efforts devoted to maintaining these memories of the past, most Pohnpeians maintain that the events of World War II do not constitute the important, precious, sacred knowledge of the past that they term poadoapoad. Stories included in this category account for the creation of Pohnpei and the features of its landscape; the settlement of the island; the origin and nature of the different matrilineal clans; the evolution of the island polity; heroic events of political consequence; matters of succession to office, precedence of rank, and chiefly prerogative; the origins of ritual forms; and so on (see Hambruch 1932, 1936; Bernart 1977).

In Pohnpeian understandings of poadoapoad, perception in the present was not the only, or even the most important, source of knowledge, and knowledge of the past and future was not necessarily regarded as episte- 
mologically inferior to knowledge of the present. Pohnpeians believed that poadoapoad had its ultimate origins in the ancestors. Knowledge from the ancestral past could be passed down by the elders through the generations, or the ancestors could communicate directly to the living through the medium of dreams or spirit possession. By whatever means it was acquired, the association of this knowledge with the revered ancestors made it important, precious, and sacred.

In addition, Pohnpeian understandings of the relationship between important forms of knowledge such as poadoapoad and the knower were quite different from common modernist understandings. In traditional Pohnpei, possession of such knowledge was an important component of personhood (Falgout I984), and highly valued forms of traditional knowledge were identified with life force. Knowledge was believed to animate the human body and to contribute to an individual's relative energy, strength, power, authority, status, personal worth, and wealth (Falgout I984). The power and status of the person who knew was in part a reflection of what that person knew. The value of knowledge was in part a reflection of the knower's status. Knowledge of the ancestral past had important social uses as well, serving to validate claims to land (in the past) and titles in the Pohnpeian chiefdoms. Especially important components of poadoapoad were the fine details - names and titles, places, numbers, and other specific aspects of the events they related (see Falgout 1984, Petersen I993; compare Gewertz and Errington I991, Lindstrom 1990).

As a key element of personal identity it was considered crucial that an individual Pohnpeian possess important forms of traditional knowledge such as poadoapoad for themselves. And because of its importance, such knowledge was not lightly given to others. Poadoapoad was considered too valuable to be widely and indiscriminately disseminated; to do so would insult the ancestors and profane the knowledge. Moreover, giving away one's important knowledge in this manner would weaken both the knowledge and the person's life force. Yet transmission was necessary for intergenerational preservation. Poadoapoad was an important form of inheritance, given only to a few exceptional individuals deemed eligible to receive it (Falgout 1984). Transmission to a chosen individual could involve a lengthy, sometimes lifelong process, and during the act of transmission there might be a considerable amount of editing and misinformation. Typically, some of the crucial details were withheld (Falgout I984; Hanlon I992, 27). When told to persons other than intended heirs, accounts tended to be general and misleading (Falgout 1984, Petersen I993). 
Pohnpeian understandings about the origin, value, and ownership of poadoapoad resulted in a very uneven distribution of knowledge about the past. The general outlines were widely understood, but social structure had a differentiating effect in that it was acknowledged that some people rightfully possessed the more detailed and authoritative versions, and that these versions could differ somewhat from one individual to another. In the past some Pohnpeian clans were said to be specialists in poadoapoad, and it was acknowledged that other clans or lineages had special rights to certain kinds of stories.

In this Pohnpeian sense (poadoapoad), what was knowledge of the past? Simply stated, it concerned the Pohnpeian people. As Sahlins has argued for Polynesia (1985), this history in Pohnpei concerned the lives and actions of important persons of high rank and their relationship to the wider society. An important component of poadoapoad concerned the origin and development of the chiefly customs (tiahk).

By definition, poadoapoad did not include outside events or outside people. And when asked, Pohnpeians explicitly stated that World War II was not really a Pohnpeian event. It was not instigated, directed, won, or lost by Pohnpeian people. Certainly, Pohnpeians were active and, at first, willing participants in the war (Falgout 1989, I991), and many Pohnpeians considered themselves loyal to the Japanese emperor. Some volunteered their service to the Japanese, even though they did not know why the war was being fought, where they might be sent, what they would be required to do, or what the personal consequences might be. Nonetheless, no matter how profound its impact on individual and collective life, World War II was an event that in most Pohnpeian minds had to do with the Japanese and the Americans. The Japanese had wished to extend colonial possessions or domination to other parts of Asia and the Pacific (Peattie I988). The Americans, enraged over the bombing of Pearl Harbor, wanted to drive the Japanese back to their home islands. The Japanese were in Pohnpei, so the Americans fought them there. Pohnpeians, they say, were just caught in the middle of this foreign war.

As knowledge of the past handed down by the revered ancestors, $p o a$ doapoad is not based on personal perception and it is certainly not the experience of everyone as told by anyone. The general willingness, openness, and enthusiasm with which Pohnpeians share their memories of the war stands in marked contrast to their treatment of knowledge of the past that is part of poadoapoad. Because personal memories of this catastrophic and culturally significant event are not conceptualized as poadoapoad, they have become such widely shared cultural memories. 


\section{The Changing Context of Pohnpeian Memories OF WORLD WAR II}

The Pohnpeian category of sacred knowledge of the past derived from the ancestors (poadoapoad) remains salient in contemporary Pohnpei, especially for the elders - the generation who lived through World War II. But of course the people of the island have undergone change, even with regard to how they think about the past. After more than one hundred seventy years of contact, including more than sixty years of an Americanrooted education system, Pohnpeians have become well acquainted with western understandings of history and its uses. Alongside the Pohnpeian view of poadoapoad exists a second, more westernized approach to the past. Today, students are exposed to a western-style chronological history, and the general outlines of poadoapoad have also become part of the school curriculum (Falgout I992). How do memories of the war fit into the complex, multifaceted representation of the past that is emerging?

Memory is an interpretive process. It is not a simple re-presenting of events as they unfolded, but rather a complex process of highlighting and erasing. Cultural memories can be preserved only through articulation, and repeated acts of narration leave traces on the memory itself. How it has been articulated in the past becomes part of how it is remembered in the present. But articulation, too, is a process, and it takes place in a social context that is itself continually changing. Thus, cultural memories (in this case Pohnpeian memories of the war) will be transformed in subtle ways over time-in significance, if not in content. In part, the changing significance of war memories may be due to the nature of the event itself, so destructive and transforming that it is likened to a force of nature. We believe that some of the most culturally significant memories of the war are being transformed into something like poadoapoad.

The tale of the Kiti men relocated to Kosrae gives some of the best evidence of the changing significance of wartime events and their absorption into the category of poadoapoad. The "Memorial Song of Kosrae" has become one of the most popular songs on the island in recent years. It was recorded by a popular singing group from the chiefdom of Uh and was broadcast over the radio station several times a day, resulting in a more general understanding of the war by people of different ages and localities and contributing to feelings of national pride among all Pohnpeians. But it also raised questions about the right to narrate the past. Not only is the Uh chiefdom a traditional rival of Kiti, but some of the survivors of 
the Kosrae experience objected to the singing group's alteration of certain small but important details in the original song.

Many of the Kiti men still survive, and other informants often referred Falgout to them for a more authoritative and detailed account of the events, much as one would refer another to a traditional expert in poadoapoad. On several occasions members of the Kiti group discussed with obvious pride the number of men sent to Kosrae or, alternatively, tried to withhold this detail. A misstatement of the number of men sent is one of the objections that the surviving Kiti men have to the recorded version of the song. Questions are also being raised over who has rights to the song and to the recounting of the experiences it describes. These issues of detailed knowledge and ownership are much like those that would arise with respect to poadoapoad.

Not only have wartime narratives raised issues of ownership and accuracy of detail similar to those surrounding poadoapoad, but they also seem to be taking on a similar significance. This change is a consequence of an evolving social and political context and memory's function as a strategic resource. Poadoapoad is sacred because it deals with the actions of the ancestors and has been transmitted either from them or through a successive line of ancestors to the present. But its importance also derives from its strategic uses in matters of succession, disputes of ownership, and displays of power.

Today in a transformed Micronesia, memories of the war are also becoming strategically important. One important strategic consideration has to do with war reparations, made to Pohnpeians by both the Americans and the Japanese. Increasingly, Pohnpeians have become vocal in stating that World War II was not their war and that they should be compensated for the hardships they were forced to endure. In making claims, it is important to have details of the hardships suffered during the wartime era. For an aging war generation up against the slow-moving governmental decision-makers in Washington and Tokyo, it might also be important that descendants have the knowledge necessary to follow up on claims. Some monies due Pohnpeians were made available by the United States government in the I980s. However, a scandal erupted when a Pohnpeian veteran charged that these funds were severely misappropriated, and a lengthy hearing ensued. A separate group, named the Sunshine Group, was formed to spur investigation into the allegations. Weekly meetings of the group served as occasions to share war experiences and to determine amounts of war claims to be made. Membership dues were used to support group 
leaders' trips to Washington, DC, in order to pursue these issues. All of these factors related to war claims emphasized the details of war recollections, which assumed strategic importance despite their lack of traditional ancestral origins.

Also of tremendous contemporary importance to Pohnpeians is their role within Micronesian and global political contexts. Although Pohnpei is currently a member, and capital, of the Federated States of Micronesia, both its relationship to the United States and its participation in the Federated States have been marked by great ambivalence. In this context, wartime experiences serve to epitomize good and bad aspects of colonial domination, and are often mentioned in social and political discussions of the present and future status of Pohnpei.

The war also held important economic lessons for Pohnpeians. Material shortages during that time served to heighten Pohnpeians' awareness of their need and desire for manufactured goods. Their economic dependency was increased during the postwar period as part of the American attempt to bind the Micronesian islands to them for strategic reasons. The war also made Pohnpeians and other Micronesians more conscious of their strategic position, a factor they have used as the major part of their economic development plan. In a sense, the Compact of Free Association can be seen as selling to the United States the right to strategic denial, if not strategic use, of the region.

Yet Pohnpeians and other Micronesians have also become profoundly aware of the ultimate social price they will be forced to pay for guaranteeing the strategic use of their islands if another conflict is brought to the area. War is an extremely high price to pay for foreign assistance, and can be forced on them without their consent or even their knowledge. World War II has taught that should war break out, the Pohnpeians will once again be relegated to the role of relatively powerless victims. Over the postwar period, they have learned that the United States, especially, is prone to wage war.

Perhaps for these reasons, decisions over the future political status of Pohnpei and the Federated States of Micronesia seem to be in a continual state of negotiation and renegotiation. Initially, looking back at the history of colonial domination, and particularly to the consequences of World War II, and mindful of the value they place on their own traditions, Pohnpei state was the most vocal of all Micronesian islands in its desire for independence. Today Pohnpei, as a member of the Federated States, is currently negotiating a renewal of the compact with the United States. 
All of this discussion about modern economics, politics, and cultural identity serves to help keep memories of the war alive, important, and useful in Pohnpei today. In this way, less important and more personal memories of World War II are becoming part of a new, western-influenced Pohnpeian vision of the past, and at the same time are beginning to be treated in ways similar to poadoapoad.

\section{Conclusion}

During her fieldwork, it was clear to Suzanne Falgout that her older informants' wartime experiences had been important to their views of themselves as individuals and as members of a generation that had endured "the greatest hardship." It was clear, too, that these experiences were being transformed into shared representations of the past, and that these cultural memories were becoming important to Pohnpeians' collective identity in the political context of independent nationhood.

The memory work of fashioning these representations is informal and small in scale, as befits the size of the community. It constitutes a kind of cottage industry whose products include stories, songs, and anecdotes, both live and spontaneous, as well as recorded performances. There is some governmental involvement as well, including the efforts of the local historic preservation office.

Our interest in this process of constructing and preserving representations of the past led us to the more general topics of the relationship between memory and identity and the role of memory as a connector between self and society. The Pohnpeian material is a reminder that identity is a process of production rather than a finished product. Through the memories of their elders and the physical remnants of the war, Pohnpeians are adding another component to their collective identity. As with all cultural constructions, it is both new and old at the same time.

Wartime stories reflect the themes and tropes of ancient tales, but in the process they yield lessons for living in a changed world.

FALGOUT'S FIELD RESEARCH was supported by an intramural grant from Idaho State University, "The Women Left Behind: Changes in Pohnpeian Women's Identity in World War II," and a National Endowment for the Humanities grant, "World War II in Micronesia: Islander Recollections and Representations" (with Lin Poyer and Laurence M Carucci). We owe a large debt of gratitude to the more than one hundred elders who so willingly shared their experiences of the war, and 
to the Pohnpei historic preservation officers and research assistants who generously offered their advice and assistance in completing these projects. We also wish to thank Geoffrey White and Lamont Lindstrom for their support and encouragement in this research. We have benefited as well from the helpful comments of the three anonymous readers of an earlier version of this paper.

\section{Notes}

I See also Carucci 1989, I995, I997; Falgout 1989, I99I; Falgout, Poyer, and Carucci 1995; George 1995; Heine 199I; Highland I99I; Higuchi 1986, I991; Hunter-Anderson and Moore I995; Laracy and White I988; Lindstrom and White I990; McQuarrie I994; Nero I989; Palomo 1984, I991; Pollock 1991; Poyer I989, I99I, I995; Poyer, Falgout, and Carucci 200I; Scarr, Gunson, and Terrell I998; Tellei I99I; White I99I; White and Lindstrom I989.

2 Ideally, Pohnpeians should look after their matrilineal clansfolk and other members of a seagoing expedition. However, once they reach the open sea, they say, "Each man considers his own life."

3 Here, the song raises a question about the manaman (power and authority) of the Japanese in conscripting and relocating these Kiti men to Kosrae, thereby risking their lives.

4 The phrase "nahnmwarki who is the ruler of the world" refers to God.

5 The "shocking news" was that the war had ended and that the Japanese had lost.

\section{References}

Bernart, Luelen

I977 The Book of Luelen. Translated and edited by John L Fischer, Saul H Riesenberg, and Marjorie G Whiting. Pacific History Series 8. Honolulu: University of Hawai'i Press.

Carucci, Laurence M

I989 The Source of the Force in Marshallese Cosmology. In White and Lindstrom, 73-96.

I995 From the Spaces to the Holes: Ralik-Ratak Remembrances of World War II. Isla: A Journal of Micronesian Studies 3 (2): 279-3I 2.

I997 Nuclear Nativity: Rituals of Renewal and Empowerment in the Marshall Islands. DeKalb: Northern Illinois University Press.

$200 \mathrm{I}$ Elision or Decision: Lived History and the Contextual Grounding of the Constructed Past. In Cultural Memory: Reconfiguring History and Identity in the Postcolonial Pacific, edited by Jeannette Marie Mageo, 8I-IOI. Honolulu: University of Hawai'i Press. 
Connerton, Paul

I989 How Societies Remember. Cambridge: Cambridge University Press.

David, Keropin

I99I Personal Interview. Pohnpei, Federated States of Micronesia. I 8 February.

DeConcini, Barbara

I990 Narrative Remembering. New York: University Press of America.

Falgout, Suzanne

I984 Persons and Knowledge in Pohnpei. PhD dissertation, University of Oregon.

I987 Master Part of Heaven: The Ethnohistory and Archaeology of Wene, Pohnpei. Micronesian Archaeological Survey 22. Saipan: US Trust Territory.

I989 From Passive Pawns to Political Strategists: Wartime Lessons for the People of Pohnpei. In White and Lindstrom, 279-297.

I99I Lessons of War from Pohnpei. In White, I23-I3I.

I992 Hierarchy vs Democracy: Two Strategies for the Management of Knowledge in Pohnpei. In Transforming Knowledge: Western Schooling in the Pacific, edited by Suzanne Falgout and Paula Levin. Theme issue of Anthropology and Education Quarterly 23 (I): 30-43.

Falgout, Suzanne, Lin Poyer, and Laurence M Carucci

I995 “The Greatest Hardship": Micronesian Memories of World War II. Isla: A Journal of Micronesian Studies 3 (2): 203-22I.

Fentress, James, and Chris Wickham I992 Social Memory. Cambridge, mA: Blackwell.

Fischer, John L, with the assistance of Ann M Fischer I957 The Eastern Carolines. New Haven, CT: HRAF Press.

George, Karen R

I995 Through a Glass Darkly: Palau's Passage through War, I944-I945. Isla: A Journal of Micronesian Studies 3 (2): 3I3-337.

Gewertz, Deborah, and Frederick Errington

I99I Twisted Histories, Altered Contexts: Representing the Chambri in the World System. Cambridge: Cambridge University Press.

Giddens, Anthony

I984 The Constitution of Society: Outline of the Theory of Structuration. Berkeley: University of California Press.

Hambruch, Paul

I932 Ergebnisse der Südsee Expedition, I908-1910, 2, B, 7, edited by Georg Thilenius. Ponape, volume I. Hamburg: Friederischsen, de Gruyter.

I936 Ergebnisse... Ponape, volumes 2 and 3.

Hanlon, David

I988 Upon a Stone Altar: A History of the Island of Pohnpei to I890. Pacific 
Islands Monograph Series 5. Honolulu: University of Hawai'i Press and Center for Pacific Islands Studies.

I992 The Path Back to Pohnsakar: Luelen Bernart, His Book, and the Practice of History on Pohnpei. Isla: A Journal of Micronesian Studies I (I): I3-36.

Hebel, Linter

I985 Personal Interview. Pohnpei, Federated States of Micronesia. I 3 June. Heine, John

I99I Marshall Islanders' Experiences in World War II. In White, I I3-I 2 I. Hezel, Francis X, S J

I983 The First Taint of Civilization: A History of the Caroline and Marshall Islands in Precolonial Days, I 52I-I 885. Pacific Islands Monograph Series I. Honolulu: University of Hawai'i Press and Center for Pacific Islands Studies.

Highland, Sam

I99I World War II in Kiribati. In White, I09-I I 2.

Higuchi, Wakako

I986 Micronesians and the Pacific War: The Palauans. Micronesian Area Research Center, University of Guam. Typescript.

I99I War in Palau: Morikawa and the Palauans. In White, I45-1 56.

Hirsch, Herbert

I995 Genocide and the Politics of Memory. Chapel Hill: University of North Carolina Press.

Hunter-Anderson, Rosalind L, and Darlene Moore

I995 Archaeology and Oral History of the Japanese Lighthouse at Yap. Isla: A Journal of Micronesian Studies 3 (2): 257-277.

Irwin-Zarecka, Iwona

I994 Frames of Remembrance: The Dynamics of Collective Memory. New Brunswick: Transaction Publishers.

Laracy, Hugh, and Geoffrey White, editors

I988 Taem Blong Faet: World War II in Melanesia. 'O 'O: A Journal of Solomon Islands Studies. Special issue. Number 4.

Lawrence, Lihna

I990 Personal Interview. Pohnpei, Federated States of Micronesia. 6 November.

Lindstrom, Lamont

I990 Knowledge and Power in a South Pacific Society. Washington, DC: Smithsonian.

Lindstrom, Lamont, and Geoffrey M White

1990 Island Encounters: Black and White Memories of the Pacific War. Washington, DC: Smithsonian Institution Press. 
I993 Singing History: Island Songs from the Pacific War. In Artistic Heritage in a Changing Pacific, edited by Philip J Dark and Roger G Rose, I 85-I96. Honolulu: University of Hawai'i Press.

Mageo, Jeannette Marie

200I On Memory Genres. In Cultural Memory: Reconfiguring History and Identity in the Postcolonial Pacific, edited by Jeannette Marie Mageo, I I-3I. Honolulu: University of Hawai'i Press.

McQuarrie, Peter

I994 StrategicAtolls: Tuvalu and the Second World War. Christchurch: Macmillan Brown Centre for Pacific Studies.

Myerhoff, Barbara G

1974 Peyote Hunt: The Sacred Journey of the Huichol Indians. Ithaca, NY: Cornell University Press.

Neisser, Ulric

I976 Cognition and Reality. San Francisco: Freeman.

Nero, Karen

I989 Time of Famine, Time of Transformation: Hell in the Pacific, Palau. In White and Lindstrom, I I7-I 47.

Palomo, Tony I984 An Island in Agony. Privately published.

I99I Island in Agony: The War in Guam. In White, I33-I44.

Peattie, Mark R

I988 Nan'yō: The Rise and Fall of the Japanese in Micronesia, I885-I945.

Pacific Islands Monograph Series 4. Honolulu: University of Hawai'i

Press and Center for Pacific Islands Studies.

Petersen, Glenn

1993 Kanegamah and Pohnpei's Politics of Concealment. American Anthropologist 95 (2): 334-352.

Pollock, Nancy J

I99I Nauruans during World War II. In White, 9I-I07.

Poyer, Lin

I989 Echoes of Massacre: Recollections of World War II on Sapwuahfik (Ngatik Atoll). In White and Lindstrom, 97-I I 5.

I99I Micronesian Experiences of the War in the Pacific. In White, 79-89.

1992 Defining History across Cultures: Insider and Outsider Contrasts. Isla: A Journal of Micronesian Studies I (I): 73-89.

I995 Yapese Experiences of the Pacific War. Isla: A Journal of Micronesian Studies 3 (2): 223-255.

Poyer, Lin, Suzanne Falgout, and Laurence M Carucci

200Ia The Typhoon of War: Micronesian Experiences in the Pacific War. Honolulu: University of Hawai'i Press. 
$200 \mathrm{Ib}$ The Impact of the Pacific War on Micronesian Identity. In Pacific Islands Societies in a Global World. Princeton, NJ: Prentice Hall. (Forthcoming)

Raidong, Andonio

I990 Personal interview. Pohnpei, Federated States of Micronesia. 2 November.

Riesenberg, Saul H

I968 The Native Polity of Ponape. Smithsonian Contributions to Anthropology Io. Washington, DC: Smithsonian Institution Press.

Rosaldo, Renato

I980 Ilongot Headhunting, I883-1974. Stanford, CA: Stanford University Press.

Sahlins, Marshall

198 I Historical Metaphors and Mythical Realities: Structure in the Early History of the Sandwich Islands Kingdom. ASAO Special Publication I. Ann Arbor: University of Michigan Press.

I985 Islands of History. Chicago: University of Chicago Press.

Scarr, Deryck, Niel Gunson, and Jennifer Ter rell I998 Echoes of the Pacific War. Canberra: Target Oceania.

Schieffelin, Edward L

1976 The Sorrow of the Lonely and the Burning of the Dancers. New York: St Martin's Press.

Sharp, Lauriston

I952 Steel Axes for Stone Age Australians. Human Organization 2:17-22. Spence, Jonathan D

I984 The Memory Palace of Matteo Ricci. New York: Viking Penguin.

Tellei, Ubal

I99I Palauans and the Japanese Military Experience. In White, I 57-I60.

Turner, James West

I997 Continuity and Constraint: Reconstructing the Concept of Tradition from a Pacific Perspective. The Contemporary Pacific 9 (2): 345-38 I.

Weiner, James $\mathrm{F}$

I99I The Empty Place: Poetry, Space, and Being among the Foi of Papua New Guinea. Bloomington: Indiana University Press.

White, Geoffrey M, editor

I99I Remembering the Pacific War. Occasional Paper 36. Honolulu: Center for Pacific Islands Studies, University of Hawai' $i$.

White, Geoffrey M, and Lamont Lindstrom, editors

1989 The Pacific Theater: Island Representations of World War II. Pacific Islands Monograph Series 8. Honolulu: University of Hawai'i Press and Center for Pacific Islands Studies. 
Whorf, Benjamin Lee

1956 Language, Thought, and Reality: The Selected Writings of Benjamin Lee Whorf, edited and with an introduction by John B Carroll. Cambridge: Massachusetts Institute of Technology Press.

Young, Michael W

I983 Magicians of Manumanua: Living Myth in Kalauna. Berkeley: University of California Press.

\section{Abstract}

While conducting fieldwork in Pohnpei, Micronesia, in the I980s and I990s, Suzanne Falgout heard poignant accounts of the Islanders' experiences during World War II. The stories and songs that she recorded reveal that for Pohnpeians the effects of the war were local and personal-a catastrophe visited on a landscape that they know in intimate terms. In this paper we discuss not only the content of these memories but also the broader role of memory in human culture. First, we critique common understandings of memory. We highlight the ability of memory to transcend time, the diversity of forms that memory can take, and the active role of humans as agents in the process of remembering. Next, we examine the similarities and differences between personal and cultural memory and the processes of transformation from individual experience to collective identity. Finally, we discuss the nature of Pohnpeian experiences in World War II and what has made them such enduring and compelling cultural memories sixty years after the war. We relate these wartime memories to traditional Pohnpeian understandings of historical knowledge and to the genres, tropes, characters, concerns, and contexts used by Pohnpeians to remember and to articulate the past. We also examine the changing nature and use of war memories as a strategic resource in the context of contemporary Micronesia.

KEYWORDS: cultural memories, ethnohistory, indigenous epistemology, Micronesia, Pohnpei, World War II 